\title{
Determination of Trace Metals in Cigarette Smoke by Flameless Atomic Absorption Spectrometry*
}

\author{
by $M$. A. Perinelli and N. Carugno \\ Monopoli di Stato, Servizio Ricerche Chimiche e Tecnologiche, Rome, Italy
}

Interest is increasing in the content of trace metals in cigarette smoke for both their toxic effects (1) and the possible synergistic influence with other harmful organic compounds (2).

There have been several investigations into the levels of trace metals in tobacco and in tobacco smoke $(3,4,5)$. As the contents to be determined are low, homogeneous and concentrated samples are required for both of the very sensitive methods currently used: neutron activation and flame atomic absorption spectrometry. These methods generally require acid treatments, concentration or solvent extraction before analysis $(6,7,8)$.

This study develops a flameless atomic absorption method to determine metals in cigarette smoke readily without those pre-treatments which are normally a source of error. To verify the delivery of metals in smoke, the relevant contents in tobacco are also determined. The results are compared with those of the flame method.

\section{EXPERIMENTAL}

\section{Materials}

Reagents: Distilled and deionized water was used in this study.

Hydrochloric, nitric, phosphoric, sulphuric acids and methanol were of analytical reagent grade.

The calibrating solutions were prepared by diluting the 1000 ppm atomic absorption standards (Fisher Scientific Company and B.D.H.).

Apparatus: Cigarettes were smoked on the apparatus shown in Fig. 1.

The aspiration was accomplished by the Varian "air sampler" pump that was properly modified and calibrated in order to reproduce the Coresta standard operating conditions.

The total particulate matter (TPM) was collected by electrostatic precipitation in a suitable glass tube.

Collecting the smoke on a Cambridge filter was also tested but the blank level was too high and it was impossible to lower it by chemical washing without decreasing the filter retention efficiency.

\footnotetext{
- Presented at the 6th International Tobacco Scientific Congress (Coresta) held in Tokyo, Japan, in November 1976.
}

The smoke gas phase was passed through a short Tygon tube to a Teflon chamber where a perforated carbon cup provided with a microporous filter was located, perfectly fitting the "air sampler" pump.

The analyses were accomplished by the Varian AA6 atomic absorption spectrophotometer with a carbon rod atomizer (Model 63). An air-acetylene burner was used for flame analyses. Absorbance values were recorded by the Perkin-Elmer 165 potentiometric recorder.

Perforated carbon cups were used for gas phase analyses and standard carbon cups for analyses of tobacco and TPM solutions.

The solutions were introduced into the atomization cell by Hamilton syringes (variable volume 1-10 $\mu \mathrm{l}$ ) with modified polyethylene tips. Each syringe was used for one single solution only.

\section{Procedure}

Commercial domestic plain $70 \mathrm{~mm}$ and filter $85 \mathrm{~mm}$ cigarettes were used. Filters were cellulose acetate.

All cigarettes were selected and conditioned according to Coresta specifications before use.

Tobacco Sample Preparation: Five cigarettes, including paper but excluding filter tip, were digested in $10 \mathrm{ml}$ of concentrated sulphuric acid. Excess acid was evaporated by gentle heating and the solution was dried, removing

Figure 1. Smoking apparatus.
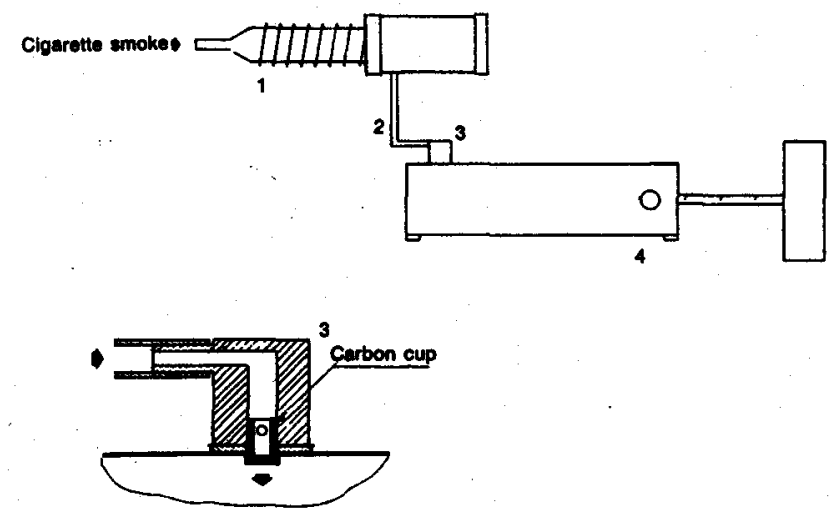

1: TPM electrostatic preclpitator 3: Gas phase trapping device 2: Tygon tube to trapping device 4: Modified Varlan air sampler 
sulphur trioxide fumes; then it was maintained at $500^{\circ} \mathrm{C}$ for 1 hour in an electric oven. Aliquots of $1.5 \mathrm{ml}$ of concentrated $\mathrm{HNO}_{3}$ were added and the drying and the baking treatment was repeated to obtain ashes with no charred material. Ashes were dissolved again in $2.5 \mathrm{ml}$ of concentrated $\mathrm{HNO}_{3}$, diluted to $50 \mathrm{ml}$ with water and analysed.

The flameless determination of $\mathrm{Pb}$ and $\mathrm{Zn}$ needed more dilute solutions.

The standard addition of trace metals to tobacco showed that no losses occur during this acid digestion.

Smoke Sample Preparation for Flameless Atomization: Ten cigarettes were smoked under Coresta standard conditions.

The collected particulate sample was dissolved in methanol and the solution transferred into a $100 \mathrm{ml}$ volumetric flask and made up to volume with the methanol washings of the glass tube. Because of the low content of the metals in the smoke, $\mathrm{Ni}$ and $\mathrm{Cd}$ determinations needed stronger solutions (the final volume was $20 \mathrm{ml}$ for $\mathrm{Ni}$, and $50 \mathrm{ml}$ for $\mathrm{Cd}$ ). The methanol solutions were analysed direct.

The smoke gas phase was retained by a disc of $0.8 \mu$ Millipore filter punched into the carbon cup by the Varian special device. $0.3 \mu$ filter was also tested, the results revealed that the retention efficiency was not improved.

To achieve low blank levels the Millipore filters were placed in a beaker and cleaned, first with $\mathrm{HCl}(1: 5)$, then with $\mathrm{HNO}_{3}(1: 5)$ and finally rinsed with water. Afterwards, they were dried by hot air and stored always in the same beaker. Filters and cups were handled with plastic tweezers.

The carbon cups with the filter disc retaining the residual traces of metals of the gas phase, were analysed direct.

Each cup permitted the determination of a single trace metal.

Smoke Sample Preparation for Flame Atomization: Ten cigarettes were smoked under Coresta standard conditions.

The particulate sample collected was dissolved in the minimum methanol volume $(10 \mathrm{ml})$ and transferred to a porcelain capsule. The solution was evaporated by gentle heating to $2 \mathrm{ml}$, then concentrated sulphuric and nitric acid were added to remove any organic charred material, finally the remaining acid solution was trans- ferred to a $25 \mathrm{ml}$ volumetric flask and made up to volume with water. This solution was analysed.

The smoke gas phase was retained by bubbling the smoke of 20 cigarettes through a liquid absorption trap, containing $50 \mathrm{ml}$ of $5 \mathrm{~N} \mathrm{HNO}_{3}$, placed before the aspirating pump. Solutions from two traps were pooled, the excess acid driven off by gentle heating and the volume reduced to $2 \mathrm{ml}$. This solution was made up to $25 \mathrm{ml}$ volume with water and analysed.

Blanks: The relevant blanks were prepared for each sample type.

Flameless Atomic Absorption Analyses: Instrument settings are shown in Table 1 for each metal.

The "dry", "ash" and "atomize" settings were so selected that the adequate temperature related to the trace metal and the sample matrix could be reached.

According to the Varian analytical guide (10), our settings approximately correspond for "dry" to 75 to $80^{\circ} \mathrm{C}-40$ seconds, and for "ash" to $800^{\circ} \mathrm{C}-40$ seconds ( $\mathrm{Pb}$ and $\mathrm{Cd}$ ) and to $900^{\circ} \mathrm{C}-25$ seconds ( $\mathrm{Zn}$ and $\mathrm{Ni}$ ).

As for the "atomize" settings, the best ramp rate was determined to reach the recommended atomizing temperature and also to obtain the best sensitivity: $\mathrm{Zn}$ $1400^{\circ} \mathrm{C}$ in 7 seconds, $\mathrm{Pb}$ and $\mathrm{Cd} 1200^{\circ} \mathrm{C}$ in 11 seconds, Ni $2200^{\circ} \mathrm{C}$ in 21 seconds.

During the useful life of a cup, owing to the altered graphite conditions, the carbon rod atomizer 63 settings slightly changed. They were checked by standard solution injections.

No special treatment was needed for the $\mathrm{Zn}$ determinations.

In order to avoid some "analyte" loss during the ashing stage, the $\mathrm{Cd}$ and $\mathrm{Pb}$ determinations were complemented by adding $2 \mu \mathrm{l}$ of $1000 \mathrm{ppm}$ phosphoric acid to the sample in the cup before analysis; standards were similarly treated.

As for the $\mathrm{Ni}$, there was no "analyte" loss during the charring stage but some interference occurred during the atomization. This trouble was overcome by using a slow ramp rate and the $\mathrm{Ni}$ atomic peak was identified by adding a fixed $\mathrm{Ni}$ standard aliquot to the sample in the cup.

The metal content of the samples was determined by interpolating the relevant calibrating curves.

For each metal, standard solutions and samples were atomized alternately. This was to avoid poor atomization

Table 1. Instrument settings for flameless atomlc absorption analyses.

\begin{tabular}{c|c|c|c|c|c|c}
\hline Metal & $\begin{array}{c}\text { Wavelength } \\
(\mathrm{nm})\end{array}$ & $\begin{array}{c}\text { Lamp current } \\
(\mathrm{mA})\end{array}$ & $\begin{array}{c}\text { Slit width } \\
(\mathrm{nm})\end{array}$ & $\begin{array}{c}\text { "Dry" } \\
\text { Voltage/Time }\end{array}$ & $\begin{array}{c}\text { "Ash" } \\
\text { Voltage / Time }\end{array}$ & $\begin{array}{c}\text { "Atomize" } \\
\text { Voltage/ Ramp rate }\end{array}$ \\
\hline $\mathrm{Zn}$ & 213.9 & 5 & 0.5 & $2.7 / 40$ & $8 / 25$ & $4.4 / 1$ \\
$\mathrm{~Pb}$ & 217.0 & 6 & 0.5 & $2.7 / 40$ & $7.5 / 40$ & $4.1 / 0.6$ \\
$\mathrm{Cd}$ & 228.8 & 3 & 0.2 & $2.7 / 40$ & $7.5 / 40$ & $4.1 / 0.6$ \\
$\mathrm{Ni}$ & 232.0 & 10 & 0.2 & $2.7 / 40$ & $8 / 25$ & $8.5 / 0.7$ \\
\hline
\end{tabular}

Note: The "dry", "ash" and "atomize" settings are initial settings; they changed slightly during the useful life of the cups. 
reproducibility due to the deterioration of the cup's pyrolytic graphite coating.

Calibration curves were determined by injecting, up to $5 \mu \mathrm{l}$, the following aqueous standard solutions: $\mathrm{Zn}$ $0.05 \mu \mathrm{g} / \mathrm{ml}, \mathrm{Pb} 0.025 \mu \mathrm{g} / \mathrm{ml}, \mathrm{Cd} 0.020 \mu \mathrm{g} / \mathrm{ml} ; \mathrm{Ni}$ $0.05 \mu \mathrm{g} / \mathrm{ml}$.

The relationship between absorption and metal concentration was linear within the calibration ranges used.

Calibration curves were checked by standard addition method: no matrix interference was revealed, the curve slope was the same as for aqueous standards.

Gas phase samples' analysis was calibrated with aqueous standard solutions injected into the perforated cup. The average absorbance value of the filter (blank value) was determined before use. Also in this case the standard addition method showed no matrix interference.

Flame Atomic Absorption Analysis: The $\mathrm{Cd}$ and $\mathrm{Pb}$ analyses were calibrated with standard aqueous solutions with the same acid content as that of the samples.

The calibration ranges made it possible to operate in the linear part of the curve.

The following metal concentrations were used: $\mathrm{Cd}$ $0.05-0.1-0.2 \mu \mathrm{g} / \mathrm{ml}, \mathrm{Pb} 0.1-0.5-1.0 \mu \mathrm{g} / \mathrm{ml}$.

\section{RESULTS AND DISCUSSION}

The results of the determination of trace metals in plain cigarettes and filter cigarettes are shown in Tables 2 and 3 respectively. Metal deliveries are also reported as ng/g tobacco, the figures are corrected for the water content of the tobacco and the actual tobacco smoked from the cigarette. The percent transfers of metals from tobacco into smoke are close to those found by previous authors $(6,9)$. Lower metal deliveries for filter cigarettes reflect the retention of the smoke by the filter; the cellulose acetate filter appears to be more effective for $\mathrm{Pb}$ and $\mathrm{Cd}$.

For the filter cigarettes, the $\mathrm{Pb}$ and $\mathrm{Cd}$ deliveries, determined by the flame and flameless method, are compared in Table 4.

The coefficients of variation (relative standard deviation) in the measurements of each type of smoke sample, for the two methods, are indicated in Table 5.

The greater sensitivity of the flameless method is clearly shown. In fact, the flame method needs so many treatments and pre-concentration steps before analysis that the results achieved are most probably influenced by the high blank values and various accidental contaminations. Moreover, the $\mathrm{Pb}$ determination by the flame method is influenced much more by the interference of non-atomic absorption.

Non-atomic absorption also affected the flameless $\mathrm{Pb}$ determinations. If one is available, it would be advisable to use a badkground corrector.

As for the $\mathrm{Zn}$ flameless determinations of the gas phase samples, it must be pointed out that the Millipore filters were found to contain high levels of zinc impurities and it was almost impossible to remove them completely by chemical washing. This resulted in a greater coefficient of variation.

Owing to the slow atomization ramp rate, the analytical sensitivity was not adequate for the $\mathrm{Ni}$ determinations

Table 2. Dellvery of trace metals from commercial plain clgarettes Into smoke.

\begin{tabular}{|c|c|c|c|c|c|c|c|c|}
\hline \multirow{2}{*}{ Metal } & \multicolumn{2}{|c|}{ Cigarette } & \multicolumn{3}{|c|}{ Total particulate matter } & \multicolumn{3}{|c|}{ Gas phase } \\
\hline & ng/cigarette & $\begin{array}{c}n g / g \text { tobacco } \\
\text { (a) }\end{array}$ & ng/cigarette & $\begin{array}{c}\text { ng/g tobacco } \\
(a, b)\end{array}$ & $\begin{array}{c}\text { Transfer }(\%) \\
\text { (c) }\end{array}$ & ng/cigarette & $\begin{array}{c}\mathrm{ng} / \mathrm{g} \text { tobacco } \\
(a, b)\end{array}$ & $\begin{array}{c}\text { Transfer }(\%) \\
\text { (c) }\end{array}$ \\
\hline $\mathrm{Zn}$ & 40,370 & 46,402 & 350 & 600.3 & 1.29 & 0.030 & 0.051 & 0.0001 \\
\hline $\mathrm{Pb}$ & 8,800 & 10,115 & 85 & 145.8 & 1.44 & 0.060 & 0.103 & 0.0010 \\
\hline Cd & 1,390 & 1,598 & 62 & 106.3 & 6.65 & 0.003 & 0.005 & 0.0003 \\
\hline $\mathbf{N i}$ & 308 & 354 & 5 & 8.6 & 2.43 & $<0.05$ & $<0.05$ & $\dot{-}$ \\
\hline
\end{tabular}

Table 3. Delivery of trace metals from commerclal filter cigarettes Into smoke.

\begin{tabular}{|c|c|c|c|c|c|c|c|c|}
\hline \multirow{2}{*}{ Metal } & \multicolumn{2}{|c|}{ Clgarette } & \multicolumn{3}{|c|}{ Total particulate matter } & \multicolumn{3}{|c|}{ Gas phase } \\
\hline & ng/cigarette & $\begin{array}{c}\text { ng/g tobacco } \\
\text { (a) }\end{array}$ & ng/cigarette & $\begin{array}{c}\text { ng/g tobacco } \\
(a, b)\end{array}$ & $\begin{array}{c}\text { Transfer }(\%) \\
\text { (c) }\end{array}$ & ng/cigarette & $\begin{array}{c}\text { ng/g tobacco } \\
(a, b)\end{array}$ & $\begin{array}{c}\text { Transfer }(\%) \\
\text { (c) }\end{array}$ \\
\hline Zn & 29,000 & 38,158 & 248 & 370.1 & 0.97 & 0.026 & 0.039 & 0.0001 \\
\hline $\mathbf{P b}$ & 6,240 & 8,210 & 34 & 50.7 & 0.62 & 0.006 & 0.009 & 0.0001 \\
\hline Cd & 1,000 & 1,316 & 41 & 61.2 & 4.65 & 0.002 & 0.003 & 0.0002 \\
\hline $\mathrm{Ni}$ & 255 & 336 & 4 & 6.0 & 1.79 & $<0.05$ & $<0.05$ & - \\
\hline
\end{tabular}

a: Data are corrected for the water content of the tobacco.

b: Data are corrected for the actual tobacco smoked from the cigarette.

c: Per cent transfer is calculated according to the relevant tobacco data. 
Table 4. Cd and Pb content of commerclal filter clgarettes (determined by flameless and flame atomic absorption spectroscopy).

\begin{tabular}{c|c}
$\begin{array}{c}\text { Flameless } \\
\text { atomic } \\
\text { absorption }\end{array}$ & $\begin{array}{c}\text { Flame } \\
\text { atomic } \\
\text { absorption }\end{array}$ \\
\hline
\end{tabular}

\begin{tabular}{cccc}
\hline Cd & Cigarette & 1.000 & 1.34 \\
& TPM & 0.041 & 0.10 \\
& Gas phase & $0.002 \times 10^{-3}$ & 0.01 \\
\hline $\mathrm{Pb}$ & Cigarette & 6.240 & 9.35 \\
& TPM & 0.034 & 0.75 \\
& Gas phase & $0.006 \times 10^{-3}$ & 0.04 \\
\hline
\end{tabular}

TPM: total particulate matter

Deliveries are reported as $\mu \mathrm{g} / \mathrm{cigarette}$

of the gas phase samples. The $\mathrm{Ni}$ amounts found in this case are close to the detection limit of the method; the coefficient of variation could not be established.

This simple and quick flameless method can be applied for the determination of any other metal in cigarette smoke; furthermore, improved sensitivity can be expected from the correction of the non-atomic absorption badkground.

Studies directed at such ends are currently in progress.

\section{SUMMARY}

A flameless atomic absorption method has been developed which permits the quick determination of the levels of trace metals in cigarette smoke. The total particulate matter (TPM) was collected by electrostatic precipitation and dissolved in methanol before analysis. In order to trap the last remaining traces of metals, the gas phase was passed through microporous filters which were analysed direct.

The sensitivity of this method for the metals studied $(\mathrm{Zn}, \mathrm{Pb}, \mathrm{Cd}, \mathrm{Ni})$ is good in both the particulate and gas phase samples, with the sole exception of $\mathrm{Ni}$ in the gas phase.

Results obtained by the flame and flameless methods are compared.

\section{ZUSAMMENFASSUNG}

Die Autoren entwickelten ein Verfahren, das auf der Basis flammenloser Atomabsorptionsspektroskopie die schnelle Bestimmung der im Cigarettenrauch enthaltenen Spurenmetalle ermöglicht. Die Gesamtpartikelphase (TPM) wurde durch elektrostatische Niederschlagung gesammelt und vor der Analyse in Methanol gelöst. Die Gasphase wurde zur Abscheidung der letzten Metallspuren durch mikroporöse Filter geleitet, welche direkt analysiert wurden.

Mit der einzigen Ausnahme des Nickels in der Gasphase erwies sich die Empfindlichkeit der Methode bei den untersuchten Metallen ( $\mathrm{Zn}, \mathrm{Pb}, \mathrm{Cd}, \mathrm{Ni}$ ) sowohl in der Partikelphase als auch in der Gasphase als gut.

Die Ergebnisse, die unter Einsatz von Flammen-Absorptionsspektroskopie einerseits und flammenloser Atomabsorptionsspektroskopie andererseits erhalten wurden, werden verglichen.
Table 5. Coefficients of varlation in the measurements of smoke samples. (determination by the flameless and flame atomic absorption spectroscopy).

\begin{tabular}{c|c}
\hline $\begin{array}{c}\text { Flameless } \\
\text { atomic } \\
\text { absorption }\end{array}$ & $\begin{array}{c}\text { Flame } \\
\text { atomic } \\
\text { absorption }\end{array}$ \\
\hline
\end{tabular}

\begin{tabular}{llrl}
\hline Total & $\mathrm{Zn}$ & $4 \%$ & - \\
particulate & $\mathrm{Pb}$ & $10 \%$ & $38 \%$ \\
matter & $\mathrm{Cd}$ & $4 \%$ & $10 \%$ \\
& $\mathrm{Ni}$ & $4 \%$ & - \\
\hline Gas phase & $\mathrm{Zn}$ & $50 \%$ & - \\
& $\mathrm{Pb}$ & $19 \%$ & $75 \%$ \\
& $\mathrm{Cd}$ & $10 \%$ & $50 \%$ \\
& $\mathrm{Ni}$ & not determined & -
\end{tabular}

\section{RESUME}

Une méthode a été mise au point pour la détermination rapide, par absorption atomique sans flamme, de la quantité de métaux en trace dans la fumée de cigarette. Le condensat de fumée (TPM) a été recueilli par précipitation électrostatique et dissous dans du méthanol avant l'analyse. Afin que les dernières traces de métaux puissent être recueillies, la phase gazeuse a été passée par des filtres microporeux qui ont été analysés directement.

La sensibilité de cette méthode est bonne en ce qui concerne les métaux étudiés $(\mathrm{Zn}, \mathrm{Pb}, \mathrm{Cd}, \mathrm{Ni})$ aussi bien pour la phase gazeuse que pour la phase particulaire, à la seule exception du $\mathrm{Ni}$ dans la phase gazeuse.

Les résultats obtenus par les méthodes avec ou sans flamme sont comparés.

\section{REFERENCES}

1. Nandi, M., H. Jick, D. Slone, S. Shapiro and G. P. Lewis: Lancet 1969-II, 1329.

2. Butler, J. D.: Chem. in Brit. 11 (1975) 358.

3. Dale, R. W., C. D, Briggs: Coresta 5th International Tobacco Scientific Congress, Hamburg, 1970.

4. Nadkarni, R. A., W. D. Ehmann: Radiochem. Radioanal. Letters 4 (1970) 325.

5. Kubota, H., M. R. Guerin, J. A. Carter: Coresta 26th TCRC Joint Conference, Williamsburg, Virginia, U.S.A., 1972.

6. Westcott, D. T., D. Spincer: Beitr. Tabakforsch. 7 (1974) 217.

7. Morie, G. P., P. E. Morrisett: Beitr. Tabakforsch. 7 (1974) 302.

8. Wyttenbach, A., S. Bajo, A. Haekkinen: Beitr. Tabakforsch. 8 (1976) 247.

9. Menden, E. E., V. J. Elia, L. W. Michael, H. G. Petering: Environ. Sci. and Techn. 6 (1972) 830 to 832.

10. Culver, B. R.: Analytical methods for carbon rod atomizer; Varian Techtron Pty. Ltd., 679 Springvale Rd., N. Springvale, Vic., 3171, Australia.

Authors' address:

Monopoli di Stato, Servizio Ricerche Chimiche e Tecnologiche, Piazza Mastai 11, Rome, Italy. 